\title{
ENR-50 Compatibilized Natural Rubber/Recycled Acrylonitrile-Butadiene Rubber Blends
}

\author{
(Penyerasian ENR-50 dalam Adunan Getah Asli/Getah Kitar Semula Akrilonitril Butadiena)
}

\author{
HAZWANI SYAZA AHMAD*, HANAFI ISMAIL \&AZURA ABD RASHID
}

\begin{abstract}
Epoxidized natural rubber (ENR-50) has been used as a compatibilizer for natural rubber-recycled acrylonitrile-butadiene rubber (NR/NBRr) blends, vulcanized by sulfur. NBR gloves have excellent resistance to punctures, tear and many types of chemicals, while NR has good physical and mechanical properties. Incorporation of ENR-50 into the rubber blends has improved processability, stiffness, resilience and excellent oil resistance. NR/NBRr blends were prepared by two-roll mill with five different compositions with the ENR-50 content fixed at $10 \mathrm{phr}$. Cure characteristics, mechanical properties and morphology (SEM) studies were performed to determine the compatibility of NR/NBRr blends in the presence of ENR50. The cure characteristics showed that NR/NBRr blends with the presence of ENR-50 have lower scorch time $\left(t_{s 2}\right)$ and cure time $\left(t_{90}\right)$ than NR/NBRr blends without ENR-50. However, the NR/NBRr blends with ENR-50 exhibited higher minimum torque $\left(M_{L}\right)$ and maximum torque $\left(M_{H}\right)$ which indicated difficult processability of the blends after compatibilization. Incorporation of ENR-50 into NR/NBRr blends improved all the tensile properties (tensile strength, tensile modulus and elongation at break) compared with NR/NBRr blends without ENR-50. The improvement in hardness upon compatibilization is due to an increase in crosslink density. Scanning electron microscopy (SEM images) of the fracture surfaces indicates that, with the addition of ENR-50 in NR/NBRr blends, better adhesion between NR and NBRr was obtained, thus improving the compatibility of NR/NBRr blends.
\end{abstract}

Keywords: Curing characteristics; ENR-50; mechanical properties; NBRr; NR; scanning electron microscopy

ABSTRAK

Getah asli terepoksida (ENR-50) telah digunakan sebagai agen pembantu pemprosesan untuk adunan getah asli/getah kitar semula akrilonitril butadiena (NR/NBRr), divulkan dengan sulfur. Sarung tangan NBR mempunyai rintangan yang baik terhadap tebuk, koyak dan pelbagai jenis bahan kimia, manakala NR mempunyai sifat fizikal dan mekanik yang baik. Penggabungan ENR-50 di dalam adunan getah telah menambah baik kebolehprosesan, kekakuan, kebingkasan dan kerintangan minyak. Lima komposisi yang berbeza untuk setiap adunan getah NR/NBRr dengan kandungan ENR-50 yang tetap sebanyak 10 phr telah disediakan menggunakan pengisar dua-gulungan. Sifat pematangan, mekanik dan morfologi (SEM) telah dijalankan untuk menentukan keserasian adunan getah NR/NBRr dengan kehadiran ENR-50. Sifat pematangan menunjukkan bahawa adunan getah NR/NBRr dengan kehadiran ENR-50 mempunyai masa skorj $\left(t_{s 2}\right)$ dan masa pematangan $\left(t_{90}\right)$ yang pendek berbanding adunan getah NR/NBRr tanpa kehadiran ENR-50. Walau bagaimanapun, adunan getah NR/NBRr dengan kehadiran ENR-50 mempamerkan tork minimum $\left(M_{L}\right)$ dan tork maksimum $\left(M_{H}\right)$ yang tinggi, yang menunjukkan bahawa kebolehprosesan adunan getah menjadi semakin sukar. Penggabungan ENR-50 ke dalam adunan getah NR/NBRr telah menambah baik semua sifat tensil (kekuatan tensil, modulus dan pemanjangan takat putus) berbanding adunan getah NR/NBRr tanpa kehadiran ENR-50. Peningkatan kekerasan di dalam adunan getah disebabkan oleh peningkatan ketumpatan sambung silang. Mikrograf SEM ke atas permukaan patah membuktikan bahawa penambahan ENR-50 ke dalam adunan getah NR/NBRr telah menambah baik pelekatan antara-muka NR dan NBRr, seterusnya meningkatkan keserasian adunan getah NR/NBRr.

Kata kunci: ENR-50; mikroskop elektron imbasan; NBRr; NR; sifat mekanik; sifat pematangan

\section{INTRODUCTION}

Nowadays, blending of two polymers has commonly been carried out in the manufacturing industry, especially rubber elastomers together with recycled rubber or waste rubber. This blending can meet the processing requirement to manufacture a wide range of products such as playground surfaces, recycled rubber flooring and sporting mats (Noriman \& Ismail 2011). Mixing of different polymers has showed a new realm of technically important materials. The properties of polymer blends can be altered by different formulation and composition (Perera et al. 2000).

The physical properties of polymer blends depend on the morphology, dispersion and stiffness of each component in the final properties of the blends (Goyanes et al. 2008). However, blending of two polymers leads to immiscibility and third component are required such 
as compatibilizer to achieve the desired properties of the final product. This compatibilizer is able to mediate an interaction between the phases (Ismail \& Hairunezam 2001; Ismail et al. 2009).

Epoxidized natural rubber (ENR-50) was known since 1922 and became commercially available in the past decade. ENR-50 is chemically modified form of the cis 1,4-polyisoprene rubber, where some of the unsaturation is converted into epoxide groups which are randomly distributed along the polymer chain. ENR-50 has good properties such as oil resistance, reduced air permeability, damping and wet grip compared to the synthetic specialty rubbers (Ismail et al. 2001, 1998; Perera et al. 2000). The incorporation of ENR-50 in the blends improved processability, stiffness, resilience and reduced the damping property. Ismail and Hairunezam (2001) reported that the scorch time, $\mathrm{t}_{\mathrm{s} 2}$ and cure time, $\mathrm{t}_{90}$ were found to decrease with the increasing of ENR composition in the blends. The mechanical properties increase with increasing ENR composition in the blends. At a similar immersion time, blends with higher composition of ENR exhibit better oil resistance.

Fang et al. (2001) stated that the rubber is one of the three main polymer material groups. The annual consumption of natural rubber is more than 15 million tons and the output of rubber products are more than 31 million tons worldwide. The increased use of acrylonitrile butadiene rubber (NBR) latex in glove manufacture has been seen over the last couple of years all over the world. The reason is its excellent resistance to punctures and tears as well as the non-existence of leachable allergeneic proteins, unlike in natural rubber latex. Nitrile gloves are currently used in many areas such as the medical and dental fields to a greater extent, food industry, automotive industry and chemical industry and as a result significant quantities of rejects are generated worldwide daily (Ismail et al. 2009).

Acrylonitrile butadiene rubber (NBR) has superior strength and excellent resistance to abrasion, oil, water, alcohols and heat in a wide range of temperatures. However, NBR shows no self-reinforcing effect because there is no crystallinity, but when used in combination with reinforcing fillers or blend with other rubbers, the excellent mechanical properties can be obtained from NBR (El-Nemr 2011; Ismail et al. 2009, 2001). Natural rubber (NR) has outstanding properties such as tensile strength, toughness and resilience because it can crystallize spontaneously when stretched. However, some properties of natural rubber such as modulus, hardness and abrasion resistance need to be improved for some specific applications (Rattanasom et al. 2009).

Other than that, the drawback of NR is that it can be easily degraded by heat and ozone. Moreover, it also possesses low oil resistance and high gas permeability which is undesirable in some applications (Jiamjitsiripong \& Pattamaprom 2011). Ismail et al. (2001) reported that the blending of NR with NBR can produce a vulcanizate with the best properties from each component. The tensile strength and elongation at break decrease, but increase in modulus as NBR content increase. This attributed to the enhancing effect of NBR and the latter increase is associated with strain-induced crystallization of the respective rubbers.

The effect of ENR-50 as compatibilizer on compatibility of rubber blends has been studied (Ismail \& Hairunezam 2001; Noriman et al. 2010). However, no attempt has been made to investigate the effects of ENR-50 as a compatibilizer on the properties of NR/NBRr blends. The effects on cure characteristics, mechanical properties and morphological behavior of NR/NBRr blends with and without ENR-50 were examined.

\section{EXPERIMENTAL DETAILS}

\section{MATERIALS}

Natural rubber (SMR L) was supplied by Guthrie (M) Sdn. Bhd. Seremban, Malaysia. The recycled NBR glove with a range of sizes from 124 to $334 \mu \mathrm{m}$ was supplied by Juara One Resources Sdn. Bhd. Bukit Mertajam, Penang, Malaysia. Epoxidized natural rubber (ENR-50) was supplied by Malaysian Rubber Board. Carbon black (N330) was purchased from Malayan Carbon (M) Ltd. The compounding ingredients such as zinc oxide $(\mathrm{ZnO})$, stearic acid, N-cyclohexyl-2-benzothiazolesulfenamide (CBS), N -isopropyl-N'-phenyl-pphenylenediamine (IPPD) and sulfur were supplied by Bayer (M) Ltd (Petaling Jaya, Malaysia).

\section{PREPARATION OF BLENDS}

The NR/NBRr blends were prepared at different blend ratios and the formulation is shown in Table 1. Five different compositions were prepared and mixed using a laboratory-sized two-roll mill $(160 \times 320 \mathrm{~mm})$, model XK-160, in accordance with ASTM method D3184-80. Cure characteristics were studied using a Monsanto Moving Die Rheometer (MDR 2000). The samples ( 4g) of the respective compounds were tested at the vulcanization temperature $\left(150^{\circ} \mathrm{C}\right)$ and the rubber compounds then were compression molded at $150^{\circ} \mathrm{C}$ using a hot press according to respective cure time, $\mathrm{t}_{90}$.

\section{MECHANICAL PROPERTIES}

Dumb-bell shaped samples were cut from the molded sheets according to ASTM D3182. Five samples were prepared for each compound. Tensile test was performed at a cross-head speed of $500 \mathrm{~mm} / \mathrm{min}$ using Universal Tester Tensile machine (Instron 3366). Tensile test were carried out according to ASTM D412-51. Hardness measurement of sample was done according to ASTM D1415-88 using Wallace dead load, with hardness ranging from 30 to 85 IRHD (International Rubber Hardness Degree).

\section{CROSSLINK DENSITY STUDY}

Measurement of the crosslink density was determined through swelling of the compound in toluene according 
TABLE 1. Formulation of NR/NBRr blends with ENR-50 as compatiblizer

\begin{tabular}{lccccc}
\hline Ingredients & \multicolumn{5}{c}{ Blend (phr) } \\
\hline NR & 85 & 80 & 75 & 65 & 55 \\
NBRr & 5 & 10 & 15 & 25 & 35 \\
ENR-50 & 10 & 10 & 10 & 10 & 10 \\
Zinc oxide & 5 & 5 & 5 & 5 & 5 \\
Stearic acid & 2 & 2 & 2 & 2 & 2 \\
Sulphur & 2 & 2 & 2 & 2 & 2 \\
CBS & 1.5 & 1.5 & 1.5 & 1.5 & 1.5 \\
IPPD & 2 & 2 & 2 & 2 & 2 \\
CB (N330) & 30 & 30 & 30 & 30 & 30 \\
\hline
\end{tabular}

to ISO 1817 or ASTM D471. Test pieces with dimensions of $30 \times 5 \times 2 \mathrm{~mm}$ were prepared from the molded sheets. Prior to the test, the initial weight of the test pieces was recorded. The test pieces were then immersed in toluene and conditioned at $25^{\circ} \mathrm{C}$ in dark environment for $72 \mathrm{~h}$. After the conditioned period, the pieces were weighed again. The pieces were dried in an oven at $70^{\circ} \mathrm{C}$ for $15 \mathrm{~min}$ and cool at room temperature for another 15 min before final weighing. Crosslink density values were obtained from Flory-Rhener equation:

$$
=-\frac{\left[\ln \left(1-v_{2}\right)+v_{2}+\chi v_{2}^{2}\right]}{v_{s}\left(v_{2}^{\frac{1}{3}}-v_{2} / 2\right)},
$$

where $\mathrm{V}_{\mathrm{s}}$ is the molar volume of the solvent, $v_{2}$ is swollen specimen and $\chi$ is the polymer-solvent interaction parameter.

\section{SCANNING ELECTRON MICROSCOPY (SEM)}

The morphologies of tensile fracture surface of NR/NBRr blends were observed under ZEISS SUPRA ${ }^{\mathrm{TM}} 35 \mathrm{VP}$ Scanning electron microscope with GEMINI field emission column. The main purpose of this test was to observe the degree of dispersion of recycled NBR in the NR and to evaluate the interaction between recycled NBR and NR. Test specimens were placed in an aluminum mount with double sided sticky tape and coated with a thin layer of gold-palladium to eliminate electrostatic charging effects during the observation.

\section{RESULTS AND DISCUSSION \\ CURE CHARACTERISTICS}

In this study, 10 phr of ENR-50 was incorporated into the NR/NBRr blends as a compatibilizer. The presences of epoxide groups in ENR-50 make it slightly more polar than NR. The cure characteristics of vulcanized rubber blends are reported in terms of scorch time $\left(\mathrm{t}_{\mathrm{s} 2}\right)$, cure time $\left(t_{90}\right)$, minimum torque $\left(M_{L}\right)$, maximum torque $\left(M_{H}\right)$ and torque difference $\left(\mathrm{M}_{\mathrm{H}}-\mathrm{M}_{\mathrm{L}}\right)$. It can be seen that scorch time $\left(\mathrm{t}_{\mathrm{s} 2}\right)$ of NR/NBRr blends with and without ENR-50 is slightly increased as NBRr content increased, while cure time $\left(\mathrm{t}_{90}\right)$ exhibited opposite trend as shown in Figures 1 and 2 . However, scorch time $\left(\mathrm{t}_{\mathrm{s} 2}\right)$ and cure time $\left(\mathrm{t}_{90}\right)$ of NR/NBRr blends with ENR-50 were shorter than NR/NBRr blends without ENR-50. The addition of ENR-50 led to increase crosslink density and shorter scorch time and cure time because the epoxy ring in ENR-50 activates the transformation of adjacent double bonds in the rubber molecules into free radicals. These radicals can quickly react and form additional crosslink with sulfur (Ismail \& Poh 2000; Ismail et al. 2001; Jiamjitsiripong \& Pattamaprom 2011; Noriman et al. 2010). The higher the concentration of the epoxide group (ENR-50 contains 50\%

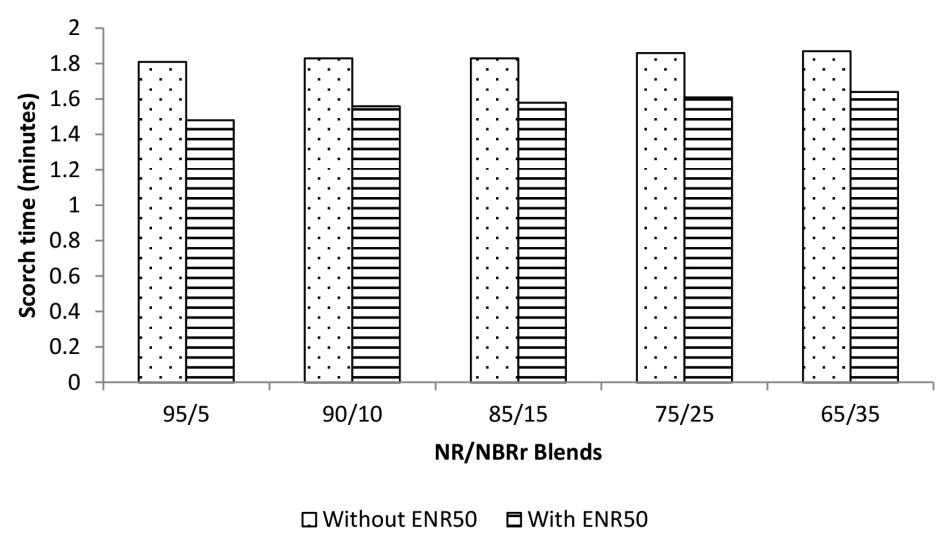

FIGURE 1. The scorch time of NR/NBRr blends with and without ENR-50 


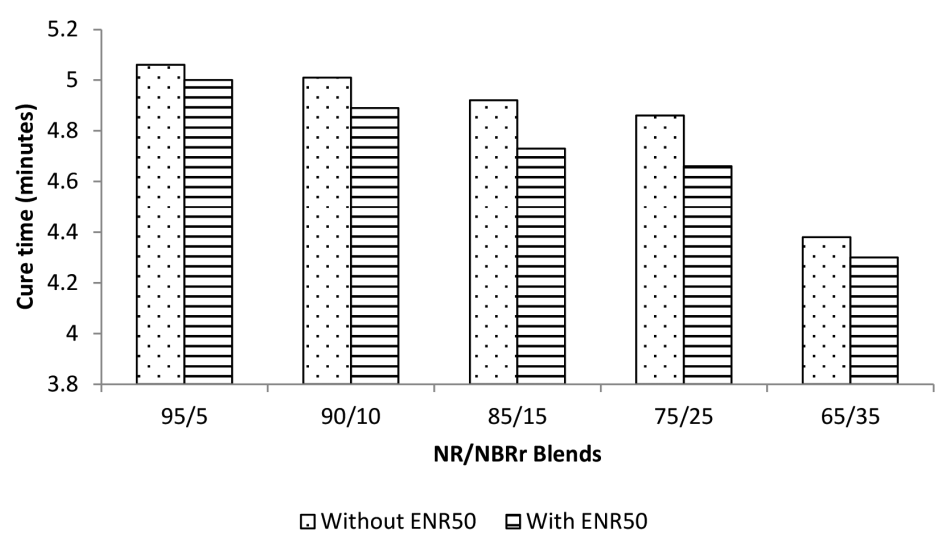

FIGURE 2. The cure time of NR/NBRr blends with and without ENR-50

of epoxide) in the rubber chain, the stronger the activation of the adjacent double bonds (Ismail \& Poh 2000; Noriman et al. 2010). Other than that, carbon black filler can accelerate reactive species and catalyzed the formation of hydrogen sulfide, which can activate the vulcanization process (Ismail et al. 2003, 1998).

The minimum torque $\left(\mathrm{M}_{\mathrm{L}}\right)$ of $\mathrm{NR} / \mathrm{NBRr}$ blends with and without ENR-50 increased with increasing recycled NBR content is shown in Figure 3. This might be due to the presence of crosslinked rubber particle of recycled NBR and reduction of NR content in NR/NBRr blends. As NBRr content increased, the flow ability of the blends is decreased, therefore increasing the $M_{L}$ (Noriman et al. 2010). However, in all blend ratios, the NR/NBRr blends with ENR-50 exhibited higher $M_{L}$ compared with NR/NBRr blends without ENR-50. The addition of ENR-50 indicates processability of the blend becomes more difficult when NBRr was increased.

Figure 4 shows the maximum torque $\left(\mathrm{M}_{\mathrm{H}}\right)$ of NR/NBRr blends with and without ENR-50 were slightly decreased with the increasing of NBRr content. This was due to the poor interaction of NR/NBRr blends. However, NR/NBRr blends with ENR-50 exhibited higher value of $\mathrm{M}_{\mathrm{H}}$ than NR/NBRr blends without ENR-50 due to the improvement incompatibility of NR/NBRr blends with the presence of ENR-50 (Noriman et al. 2010). The torque difference ( $\mathrm{M}_{\mathrm{H}^{-}}$ $M_{L}$ ) value of NR/NBRr blends with ENR-50 is slightly higher than NR/NBRr blends without ENR-50. Ismail and Poh (2000) and Ismail et al. (2001) discussed that in normal sulfur vulcanizing system, the efficiency ENR-50 vulcanization seemed to be improved. The isolated double bonds in ENR-50 inhibit the formation of intramolecular sulphide links thus resulting in the increase of the crosslinking rate (Ismail \& Poh 2000; Ismail et al. 2001).

\section{MECHANICAL PROPERTIES}

The effect of ENR-50 on the tensile strength of NR/NBRr blends is shown in Figure 5. It can be seen that the tensile strength decreased as recycled NBR increased for NR/NBRr blends with or without ENR-50. The reduction of tensile strength was due to the incompatibility in the NR/NBRr blends. Also, poor dispersion of NBRr in the NR matrix due to the presence of crosslink precursor in the rubber phase. When more recycled NBR was added with NR, it reduced the compatibility of the blends. It is well known that physico-mechanical properties of NR and NBR will drop due to the fact that NBR has greater polarity than NR

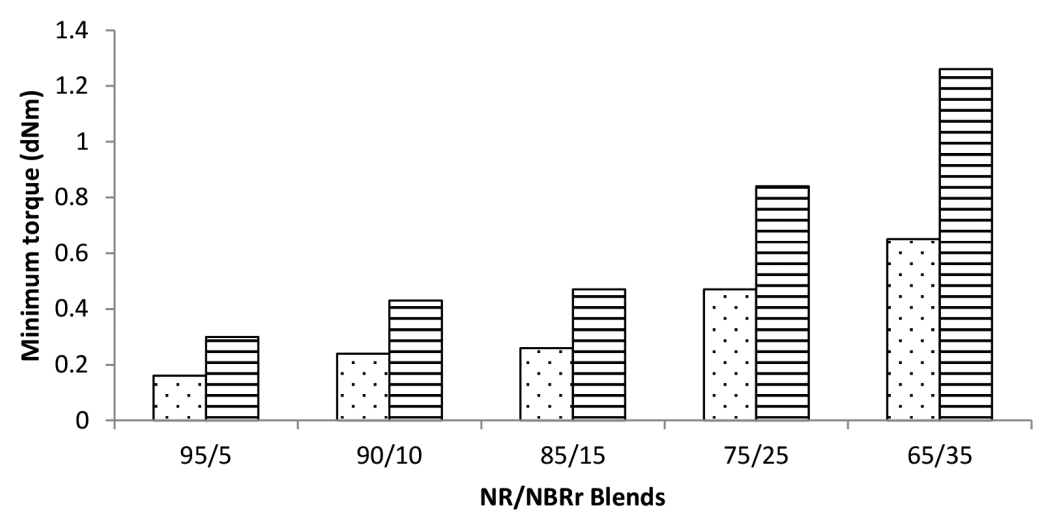

$\square$ Without ENR50 日With ENR50

FIGURE 3. The minimum torque of NR/NBRr blends with and without ENR-50 


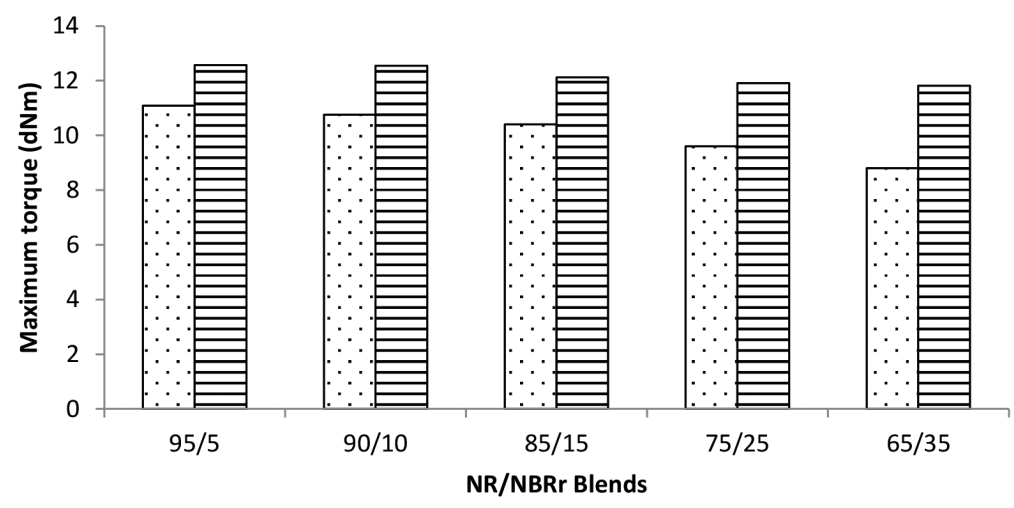

$\square$ Without ENR50 घWith ENR50

FIGURE 4. The maximum torque of NR/NBRr blends with and without ENR-50

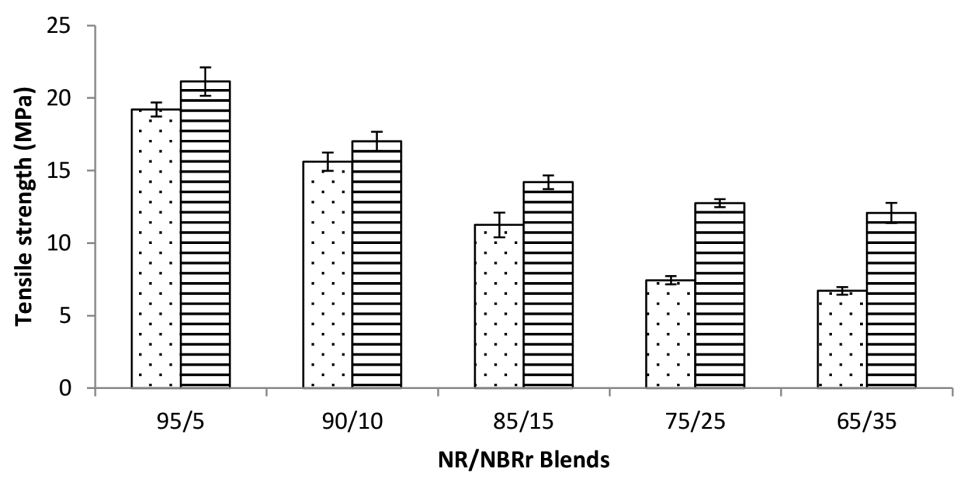

$\square$ Without ENR50 घWith ENR50

FIGURE 5. The tensile strength of NR/NBRr blends with and without ENR-50

(Ismail et al. 2009, 2001; Noriman et al. 2008; Zulkepli et al. 2009). However, with the incorporation of ENR-50 in NR/NBRr blends, the tensile strength of the blends was improved. This was due to better distribution of recycled NBR in the NR matrix with the presence of ENR-50 and improves interfacial adhesion of NR/NBRr blends by reducing the interfacial energy between phases. ENR-50 can help improving both the adherence of fillers to the rubber matrices and the strength of the crosslink bonds (Jiamjitsiripong \& Pattamaprom 2011; Noriman et al. 2010; Rajasekar et al. 2009). Other than that, higher value of tensile strength was because of larger surface area of carbon black, which gives rise to a greater interaction between the filler and rubber matrix (Ismail et al. 1998).

The effect of ENR-50 on elongation at break (Eb) is shown in Figure 6. It can be seen that the elongation at break $(\mathrm{Eb})$ decreased with the increasing of NBRr content. The decreasing effect was due to the lower molecular weight and the presence of reinforcing filler in the recycled NBR which restricts the mobility of NR and recycled rubber chains and causes the sample to fail at lower elongation. Increased in crosslink density and non-crystallizable property of NBRr has contributed to the decrease in Eb value (Ismail et al. 2001; Noriman et al. 2010). It can be seen that the NR/NBRr blends with addition of ENR-50 had higher value compared to NR/NBRr blends without ENR-50. Incorporation of ENR-50 into NR/ NBRr blends improved the compatibility of the blends and better interaction between blends, thus being able to elongate at higher strain. Other than that, the isolated double bonds in ENR-50 inhibited the formation of intramolecular sulphide links. Consequently increased the crosslinking rate which results in reduction of $\mathrm{Eb}$ (Ismail \& Hairunezam 2001; Noriman et al. 2010)

The effect of ENR-50 on variation in modulus, M100 (at 100\% elongation) and M300 (at 300\% elongation) are shown in Figure 7. The results indicated that M100 and M300 increased as recycled NBR content increased. It could be due to the NBRr behaves like rigid particulate filler since it has higher modulus than the NR matrix. This observation is related with the decreasing effect of strain-induced crystallization as NBRr content increased. NR/NBRr blend has lower tensile strength due to the noncrystallizable nature of the rubber. However, NR/NBRr blends with ENR-50 had higher value compared with the NR/NBRr blends without ENR-50 for both modulus.

The effect of ENR-50 on hardness of NR/NBRr blends was illustrated in Figure 8. It can be seen that the hardness 


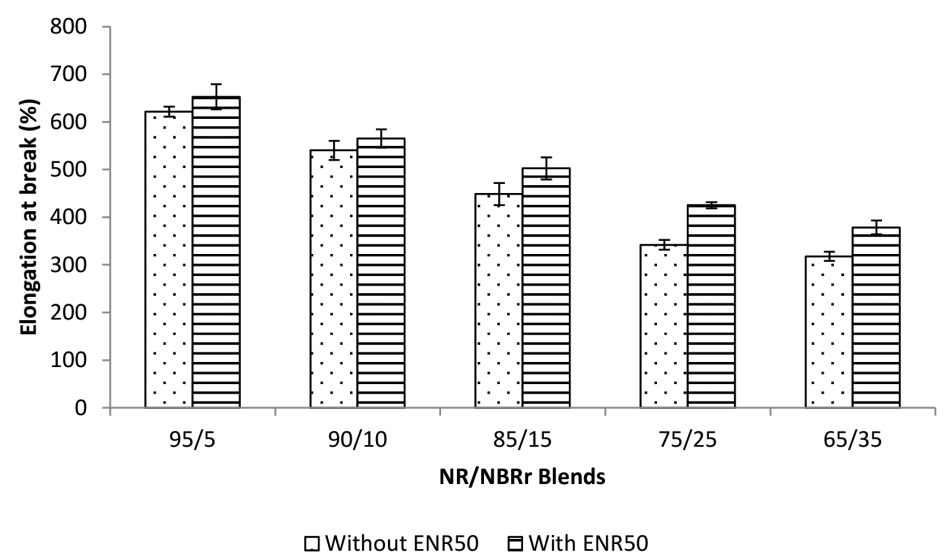

FIGURE 6 . The elongation at break of NR/NBRr blends with and without ENR-50

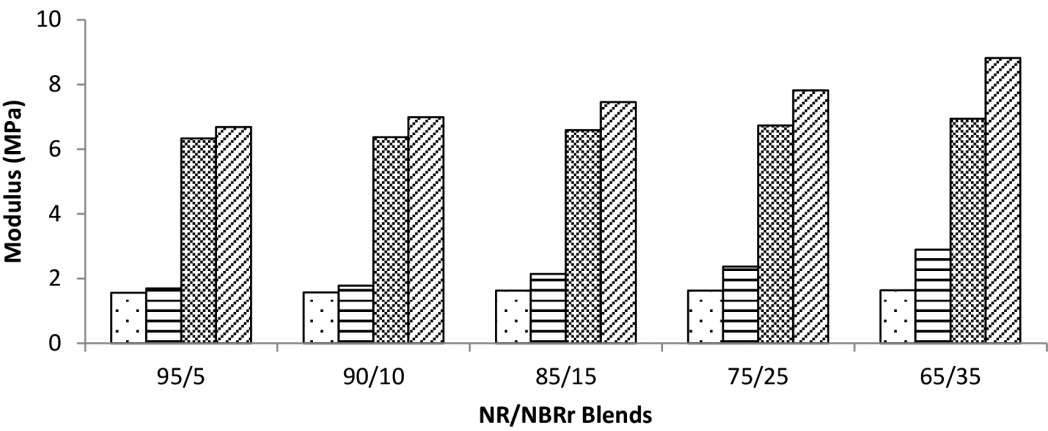

$\square$ M100 (Without ENR50) $\boxminus$ M100 (With ENR50)

M M300 (Without ENR50) $0 \mathrm{M} 300$ (With ENR50)

FIGURE 7. The modulus of NR/NBRr blends with and without ENR-50

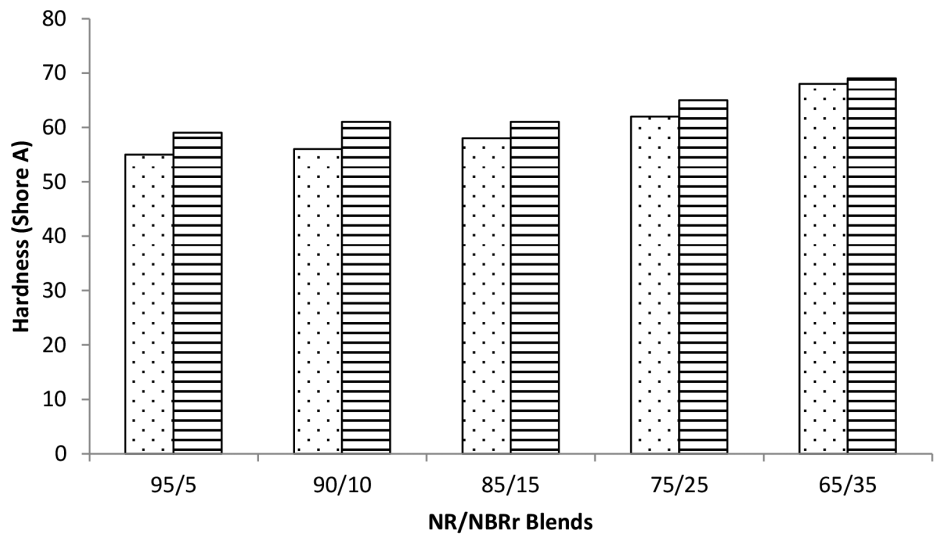

$\square$ Without ENR50 घWith ENR50

FIGURE 8. The hardness of NR/NBRr blends with and without ENR-50

is slightly increased as NBRr content increased. Increasing in hardness was due to the improvement in crosslink density of the blend. The flexibility and elasticity of the rubber chain was reduced when more recycled NBR were incorporated into NR, which also resulted in more rigid rubber vulcanizates and increase in hardness due to the presence of carbon black and active crosslink sites in the reclaimed rubber (Ismail et al. 2003; Noriman et al. 2010, 2008; Rattanasom et al. 2005; Zulkepli et al. 2009). The enhancement on hardness was due to the better dispersion of recycled NBR in the NR matrix and rubber-filler interaction (Rajasekar et al. 2009). 


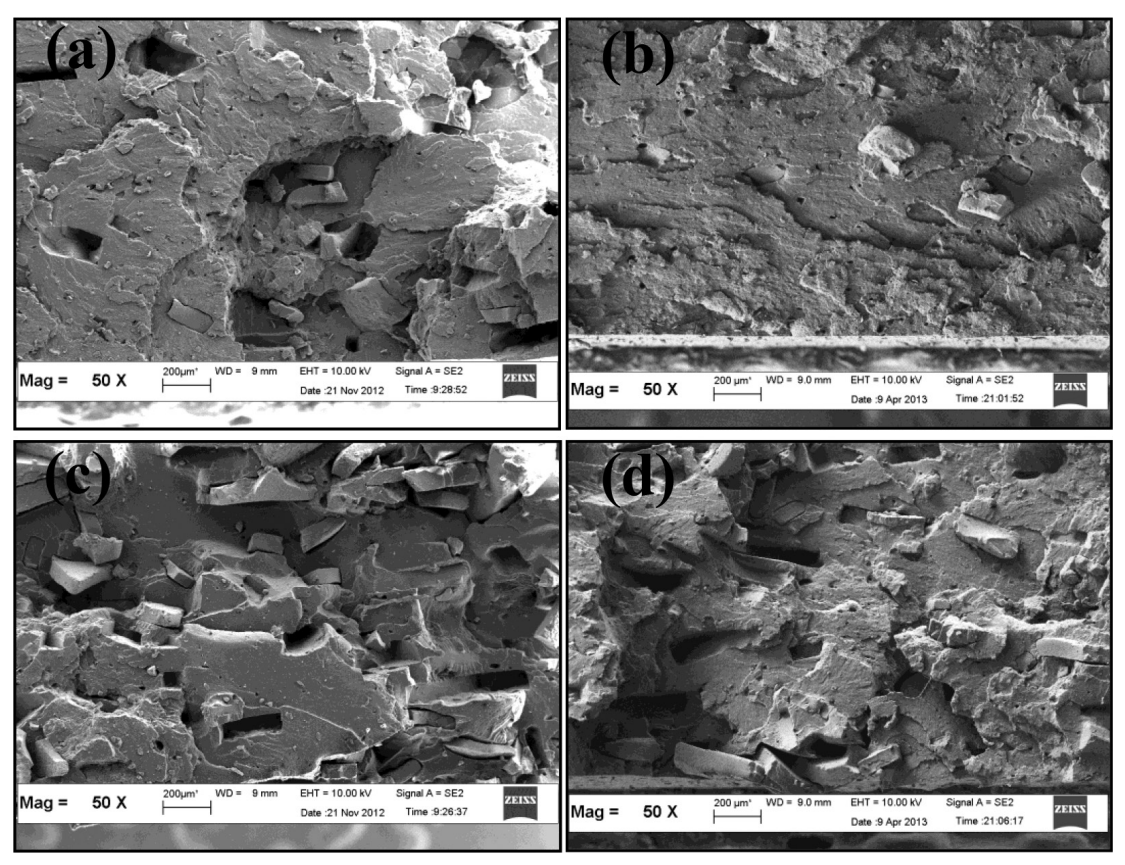

FIGURE 9. SEM micrographs showing tensile fracture surface of NR/NBRr blends at $95 / 5$ blend ratio (a) without ENR-50 and (b) with ENR-50; 65/35 blend ratio (c) without ENR-50 and

(d) with ENR-50 at 50× magnification

\section{MORPHOLOGICAL STUDY}

The SEM micrograph of the tensile fracture surface in Figure 9(a) and 9(b) shows the NR/NBRr blends at $95 / 5$ blend ratio. Figure 9 (b) shows that NR/NBRr blend with ENR-50 has rougher surface and many matrix tear lines with branching compared to Figure 9(a), which displayed a broader tearing line. This pattern indicates the higher tensile strength of the NR/NBRr blend with ENR-50. Ismail and Ahmad (2013) reported that this type of failure surface indicates that higher strength is needed to cause a catastrophic failure. Many tearing lines on the failure surface shows that the rubber can receive a lot of deformation before it break. The rubber must be in higher strength to hold higher force deformation before it breaks. Also, Figure 9(b) shows the good interaction between NR and NBRr with the presence of ENR-50. The presence of more tear lines on the fracture surface indicated the effect of increased interaction between phases, thus improving the compatibility and enhancing the tensile strength (Noriman et al.2010). Figure 9(c) and 9(d) shows the NR/NBRr blends at $65 / 35$ blend ratio with and without ENR-50, respectively. It can be seen that, Figure 9(c) and 9(d) shows many void or loose recycled NBR on the failure surface which indicates a weak recycled NBR-matrix interaction. The extensive of recycled NBR pull-out clearly provides supporting evidence for the poor tensile strength when more recycled NBR was used. However, the surface of NR/NBRr blends with ENR50 (Figure 9(d)) displays better adhesion between NR and NBRr. The NBRr is still well bonded with the NR matrix. It means that strong interfacial adhesion and effective wetting between NBRr and NR has occurred in the rubber blend (Noriman et al. 2008).

\section{CONCLUSION}

The incorporation of ENR-50 in NR/NBRr blends have lower scorch time $\left(\mathrm{t}_{\mathrm{s} 2}\right)$ and cure time $\left(\mathrm{t}_{90}\right)$ than NR/NBRr blends without ENR-50. However, the NR/NBRr blends with ENR50 exhibited higher minimum torque $\left(\mathrm{M}_{\mathrm{L}}\right)$ and maximum torque $\left(\mathrm{M}_{\mathrm{H}}\right)$ which indicated difficult processability of the blends after compatibilization. Incorporation of ENR-50 into NR/NBRr blends improved all the tensile properties (tensile strength, tensile modulus and elongation at break) compared to NR/NBRr blends without ENR-50. The improvement in hardness upon compatibilization is due to an increase in crosslink density. Scanning electron microscopy (SEM) images of the fracture surfaces indicates that, with the addition of ENR-50 in NR/NBRr blends, better adhesion between NR and NBRr was obtained, thus improving the compatibility of NR/NBRr blends.

\section{ACKNOWLEDGEMENTS}

Hazwani Syaza Ahmad is grateful to the Ministry of Education (MOE), Malaysia for the financial support under MyBrain15(MyPhD) Programme for her PhD study. Also, we would like to express our gratitude to USM for supporting most of the facilities and instruments used in this work.

\section{REFERENCES}

El-Nemr, K.F. 2011. Effect of different curing systems on the mechanical and physic-chemical properties of acrylonitrile butadiene rubber vulcanizates. Materials and Design 32: 3361-3369. 
Fang, Y., Zhan, M. \& Wang, Y. 2001. The status of recycling of waste rubber. Materials and Design 22: 123-127.

Goyanes, S., Lopez, C.C., Rubiolo, G.H., Quasso, F. \& Marzocca, A.J. 2008. Thermal properties in cured natural rubber/styrene butadiene rubber blends. European Polymer Journal 44: 1525-1534.

Ismail,H. \& Ahmad,H.S. 2013. Effect of halloysite nanotubes on curing behavior, mechanical, and microstructural properties of acrylonitrile-butadiene rubber nanocomposites. Journal of Elastomers and Plastics 46: 483-498.

Ismail, H. \& Hairunezam, H.M. 2001. The effect of a compatibilizer on curing characteristics, mechanical properties and oil resistance of styrene butadiene rubber/ epoxidized natural rubber blends. European Polymer Journal 37: $39-44$

Ismail, H. \& Poh, B.T. 2000. Cure and tear properties of ENR 25/SMR L and ENR 50/SMR L blends. European Polymer Journal 36: 2403-2408.

Ismail, H., Galpaya, D. \& Ahmad, Z. 2009. Comparison of properties of polypropylene (PP)/virgin acrylonitrile butadiene rubber (NBRv) and polypropylene (PP)/recycled acrylonitrile butadiene rubber (NBRr) blends. PolymerPlastics Technology and Engineering 48: 440-445.

Ismail, H., Galpaya, D. \& Ahmad, Z. 2009. The compatibilizing effect of epoxy resin (EP) on polypropylene (PP)/recycled acrylonitrile butadiene rubber (NBRr) blends. Polymer Testing 28: 363-370.

Ismail, H., Nordin, R. \& Noor, A.M. 2003. The effects of recycle rubber powder (RRP) content and various vulcanization systems on curing characteristics and mechanical properties of natural rubber/RRP blends. Iranian Polymer Journal 12(5): 373-380.

Ismail, H., Poh, B.T., Tan, K.S. \& Moorthy, M. 2003. Effect of filler loading on cure time and swelling behaviour of SMR L/ENR 25 and SMR L/SBR blends. Polymer International 52: 685-691.

Ismail, H., Tan, S. \& Poh, B.T. 2001. Curing and mechanical properties of nitrile and natural rubber blends. Journal of Elastomers and Plastics 33: 251-262.

Ismail, H., Ishiaku, U.S., Arinab, A.R. \& MohdIshak, Z.A. 1998. Epoxidized natural rubber compounds: Effect of vulcanization systems and fillers. Polymer-Plastics Technology and Engineering 37(4): 469-481.

Jiamjitsiripong, K. \& Pattamaprom, C. 2011.Effect of epoxidized natural rubber on gas barrier and mechanical properties of NR/BIIR composites. Journal of Elastomers and Plastics 43: 341-355.

Noriman, N.Z. \& Ismail, H. 2011. The effects of electron beam irradiation on the thermal properties, fatigue life and natural weathering of styrene butadiene rubber/recycled acrylonitrile-butadiene rubber blends. Materials and Design 32: 3336-3346.
Noriman, N.Z., Ismail,H. \& Rashid,A.A. 2010. Characterization of styrene butadiene rubber/recycled acrylonitrile-butadiene rubber (SBR/NBRr) blends: The effects of epoxidized natural rubber (ENR-50) as a compatibilizer. Polymer Testing 29: 200-208.

Noriman, N.Z., Ismail, H. \& Rashid, A. 2008. Curing characteristics and mechanical and morphological properties of styrene butadiene rubber/virgin acrylonitrile-butadiene rubber (SBR/vNBR) and styrene butadiene rubber/recycled acrylonitrile-butadiene rubber (SBR/rNBR) blends. PolymerPlastics Technology and Engineering 47: 1016-1023.

Perera, M.C.S., Ishiaku, U.S. \& Ishak, Z.A.M. 2000. Thermal degradation of PVC/NBR and PVC/ENR50 binary blends and PVC/ENR50/NBR ternary blends studied by DMA and solid state NMR. Polymer Degradation and Stability 68: 393-402.

Rajasekar, R., Pal, K., Heinrich, G., Das, A. \& Das, C.K. 2009. Development of nitrile butadiene rubber-nanoclay composites with epoxidized natural rubber as compatibilizer. Materials and Design 30: 3839-3845.

Rattanasom, N., Prasertsri, S. \& Ruangritnumchai, T. 2009. Comparison of the mechanical properties at similar hardness level of natural rubber filled with various reinforcing-fillers. Polymer Testing 28: 8-12.

Rattanasom, N., Poonsuk, A. \& Makmoon, T. 2005. Effect of curing system on the mechanical properties and heat aging resistance of natural rubber/tire tread reclaimed rubber blends. Polymer Testing 24: 728-732.

Zulkepli, N.N., Ismail, H. \& Rashid, A. 2009. Effects of different particle sizes of recycled acrylonitrile-butadiene rubber and its blend ratios on mechanical and morphological properties and curing characteristics of SBR/NBRr blends. Iranian Polymer Journal 18(2): 139-148.

School of Materials and Mineral Resources Engineering Universiti Sains Malaysia 14300 Nibong Tebal, Pulau Pinang Malaysia

*Corresponding author; email: hazwanisyazaahmad@gmail.com

Received: 15 January 2014

Accepted: 15 November 2014 